\title{
Hair growth-promoting effect of recombinant human sonic hedgehog proteins
}

\author{
Shin-Hye Yu', Yujin Kim', Narae Jung ${ }^{1}$, Jung Wook Hwang ${ }^{2}$, Nayoung Kim¹, Jong-Cheon Ha ${ }^{1}$, Mi Jin Kim', \\ Youngjun Lee ${ }^{1}$, Yong-Soo $\mathrm{Choi}^{2}, \mathrm{Kyuboem} \mathrm{Han}^{1 *}$ and Chun-Hyung Kim ${ }^{1 *}$ (D)
}

\begin{abstract}
Background: Hair loss, known as alopecia, causes psychological stress and influences social interactions. At present, treatment for hair loss is somewhat limited, transient, and unpredictable. Based on the critical role of sonic hedgehog (Shh) in hair follicle development, Shh itself would be a good therapeutic candidate for the prevention of hair loss as well as promotion of hair growth.

Methods: To investigate its potential use for hair treatment, we overexpressed Shh protein in E.coli by making silent mutations in 12 amino acids from N-terminus of Shh and purified it with Ni-affinity chromatography.

Results: Purified Shh proteins were able to activate Gli-responsive luciferase reporter gene in a dose-dependent manner and induce the alkaline phosphatase (AP) activity in the presence of bone morphogenic protein 4 (BMP-4). In addition, we confirmed that the treatment of recombinant Shh proteins to human dermal papilla (hDP) cells significantly increased the expressions of Shh-responsive genes as well as hair growth-related genes. Finally, we found that the administration of Shh proteins into the dorsal skin of the mouse could promote the hair density and length.
\end{abstract}

Conclusion: Exogenous Shh proteins induced hair-related gene expression by stimulating both Shh signaling pathway and Wnt/ß-catenin pathway in DP cells, and might therefore be a potential hair promoting agent.

Keywords: Recombinant sonic hedgehog, Random mutation, Hair growth, human dermal papilla

\section{Background}

Hair loss is a psychologically devastating disease in humans, leading to take impact on social interactions. Hair loss may be due to genetic reasons and/or external factors such as environmental pollution and work stress. To date, there are only two anti-hair loss drugs, finasteride and minoxidil, which have been used in clinical, but the effect of these drugs is limited, transient, and somewhat unpredictable (Meidan \& Touitou, 2001; Dallob et al., 1994). Therefore, it is necessary to develop novel pharmacological treatments.

Hair follicles are complex mini-organs and have hair growth cycle through periods of anagen (growth phase),

\footnotetext{
* Correspondence: kbhan@paeanbio.com; chkim@paeanbio.com ${ }^{1}$ Paean Biotechnology, Inc., 160 Techno-2-ro, Yuseong-gu, Daejeon 34028, South Korea

Full list of author information is available at the end of the article
}

catagen (regression phase), and telogen (quiescent phase) during postnatal life (Stenn \& Paus, 2001). Dysregulation of the hair growth cycle has been associated with hair loss. During hair development, the Shh signaling has a critical role in hair follicle morphogenesis and growth by regulating mesenchymal and epithelial cells of the hair follicle. Its signaling contributes to hair growth by promoting the transition from telogen to anagen during hair follicle cycle (Chiang et al., 1999; Woo et al., 2012). In supporting of this, antibodies against Shh have been shown to prevent hair growth in adult mice (Wang et al., 2000). In addition, a study of loss-of-function in Shh demonstrated the impairment of hair follicle development and of hair growth in Shh deficient skin grafted onto nude mice (Chiang et al., 1999; St-Jacques et al., 1998). Gain-of-function studies in mouse model showed that forced expression of Shh promoted the transition

(C) The Author(s). 2019 Open Access This article is distributed under the terms of the Creative Commons Attribution 4.0 International License (http://creativecommons.org/licenses/by/4.0/), which permits unrestricted use, distribution, and 
from telogen to anagen in the hair follicle cycle and concomitantly accelerated the onset of hair growth (Sato et al., 1999). Moreover, topical treatment of agonist activating hedgehog signaling into adult mouse skin showed induction of anagen and hair growth by upregulating Gli, Ptc1, and Shh genes (Paladini et al., 2005).

Based on the important roles of Shh in the hair follicle development and hair growth, we hypothesized that direct application of Shh proteins in postnatal skin would promote the hair growth. To make it, we successfully overexpressed Shh protein in Escherichia coli by making silent mutations in 12 amino acids from $\mathrm{N}$-terminus of Shh and purified it with Ni-affinity chromatography. Purified Shh proteins were able to activate Gli-responsive luciferase reporter gene in a dose-dependent manner. In addition, Shh proteins could induce the AP activity in the presence of BMP-4. Furthermore, we confirmed that treatment of recombinant Shh proteins to hDP cells significantly increased the expression of Shh-responsive genes. Finally, we found that the administration of Shh proteins into the dorsal skin of the mouse could promote the hair density and length. Together, the application of exogenous Shh proteins may be a potential therapeutic medication for alopecia by promoting hair growth.

\section{Methods}

\section{Plasmid constructions}

cDNA encoding an N-terminal fragment of Shh (24-197 amino acid residues in the human Shh gene sequence) was amplified by RT-PCR from human cDNA library using forward 5'-GGA TTC CAT ATG ATC ATC GGA CCG GGC AGG GG-3' and reverse 5'-AAA AAA CTC GAG TTA GCC TCC CGA TTT GGC CGC CAC CG3' oligonucleotides. Plasmid pET15b Shh was obtained by Shh PCR amplification followed by digesting with restriction enzyme Nde I and Xho I and cloning into plasmid pET15b (Novagen) resulting in the expression of N-terminal fragment of Shh protein. Based on the wobble hypothesis, the 12 amino acids in the $5^{\prime}$ end region of Shh were changed by PCR using forward 5'GGA TCC CAT ATG ATH ATH GGN CCN GGN AGR GGN TTY GGN AAR AGR AGR CAC CCC AAA AAG CTG ACC CCT TTA GC-3' and reverse 5' ${ }^{\prime}$-AAA AAA CTC GAG TTA GCC TCC CGA TTT GGC CGC CAC CG-3' oligonucleotides. The PCR products were digested with Nde I and Xho I and subsequently subcloned into pET15b. The integrity of all sequences was verified by DNA sequence analyses.

The plasmid containing eight tandem copies of the Gli-binding element (5'-GACCACCCA-3') upstream of the minimal promoter was generated as follows. Sense (5'-CTA GC G ACC ACC CAG ACC ACC CAG ACC ACC CAG ACC ACC CAG ACC ACC CAG ACC ACC CA G ACC ACC CAG ACC ACC CAG-3') and antisense (3'-GCT GGT GGG TCT GGT GGG T CT GGT GGG TCT GGT GGG TCT GGT GGG TCT GGT GGG TCT GGT GGG T CT GGT GGG TCG ATC-5') oligonucleotides were annealed first to generate double-stranded DNA. The annealed DNA retained a 5' overhang sequence (CTAG) at both ends and was inserted into the $\mathrm{XbaI}$ site upstream of minimal promoter of TATA-luciferase, resulting in the plasmid p8xGBE-Luc.

\section{Preparation of recombinant human Shh expressed in Escherichia coli}

Shh proteins were prepared from Escherichia coli BL21(DE3)pLysS transformed with pET15b Shh plasmid DNA. The expression of Shh-N was induced with isopropyl- $\beta$-d thiogalactoside (IPTG) at $20^{\circ} \mathrm{C}$. Harvested cells were suspended in lysis buffer $(50 \mathrm{mM}$ sodium phosphate, $300 \mathrm{mM}$ sodium chloride) and disrupted by sonication. After centrifugation, the soluble fraction was applied to a nickel column pre-equilibrated with $50 \mathrm{mM}$ sodium phosphate ( $\mathrm{pH}$ 7.4), and protein bound to nickel resin was eluted with imidazole in $50 \mathrm{mM}$ sodium phosphate ( $\mathrm{pH}$ 7.4). Fractions containing Shh proteins were dialyzed overnight against phosphate-buffered saline ( $\mathrm{pH}$ 7.4). Then, his-tag was removed by the addition of a total of 1 unit of human thrombin (Sigma) for $15 \mathrm{~min}$ at room temperature. Protein content and purity of the eluent were analyzed by BCA protein assay kit (Thermo scientific) and SDS-PAGE analysis, respectively.

\section{Luciferase reporter assay}

NIH 3 T3 cells were maintained in Dulbecco's modified Eagle's medium (DMEM) supplemented with $10 \%$ bovine calf serum (Welgene, Korea). The cells were incubated at $37^{\circ} \mathrm{C}$ in a $5 \%(\mathrm{v} / \mathrm{v}) \mathrm{CO}_{2}$ humidified atmosphere. One day before transfection, cells were plated in individual wells of 24 -well plates at a density of $2 \times 10^{5}$ cells/well. Cells were transfected with $0.375 \mu \mathrm{g}$ of a plasmid p8xGBE-luc containing eight copies of Gli-binding elements and $0.125 \mu \mathrm{g}$ of a plasmid expressing $\beta$-galactosidase (pRSV $\beta$ gal) using Lipofectamine LTX Plus Reagent (Invitrogen, USA). Twenty-four hours after transfection, cell lysates were prepared, and luciferase activities were analyzed using Glomax navigator (Promega, USA). To correct for differences in transfection efficiencies, luciferase activity was normalized to $\beta$-galactosidase activity.

\section{Measurement of alkaline phosphatase activity}

Mouse myoblast cell line $\mathrm{C}_{2} \mathrm{C}_{12}$ was maintained $(5 \%$ $\mathrm{CO}_{2}$ at $37^{\circ} \mathrm{C}$ ) in Dulbecco's modified Eagle's medium supplemented with $10 \%$ fetal calf serum. $\mathrm{C}_{2} \mathrm{C}_{12}$ cells were plated in 24-well plates at $5 \times 10^{4}$ cells per well, grown for $24 \mathrm{~h}$, and treated with BMP-4, Shh, or BMP$4 / \mathrm{Shh}$ in serum-free media for $72 \mathrm{~h}$. Alkaline phosphatase (AP) activity was determined in cell lysates using an 
AP lysis kit (Abcam). AP activity was normalized for total cell lysate's protein concentration.

\section{RNA isolation and quantitative real-time PCR (qPCR)} hDP cells were cultured in DMEM supplemented with $10 \%$ fetal bovine serum (Welgene, Korea). The cells were incubated at $37^{\circ} \mathrm{C}$ in a $5 \%(\mathrm{v} / \mathrm{v}) \mathrm{CO}_{2}$ humidified atmosphere. Eighty percent confluent of hDP cells were starved under $0.5 \%$ charcoal-activated serum condition and treated with recombinant Shh protein for $18 \mathrm{~h}$. Total RNA was isolated from cells using TRIzol reagent (Invitrogen, USA) and cDNA was synthesized using M-MLV cDNA synthesis kit (Enzynomics, Korea) according to the manufacturer's instructions. The synthesized cDNA was amplified by polymerase chain reaction using Mic Real-Time PCR (Bio Molecular Systems). Quantitative real-time PCR was performed using SYBR green mix specific for each gene. The expression of the target mRNA was normalized as a ratio using the expression of the $\beta$-actin. The primer pairs for RT-PCR were as follows:

\begin{tabular}{|c|c|c|}
\hline Gene & Forward & Reverse \\
\hline Gli1 & $\begin{array}{l}\text { 5'-GGGATGATCCCACATCCT } \\
\text { CAGTC-3' }\end{array}$ & 5'-CTGGAGCAGCCCCCCCAGT-3' \\
\hline Gli2 & 5'-ACACGGGCTITGGTCTCA-3' & 5'-CCCTTGGGCATAGCTTCT-3' \\
\hline Gli3 & 5'-ACCATGGGCTTCAGTCAG-3' & 5'-CAATCTGCACGCCTTCTA-3' \\
\hline $\begin{array}{l}\text { Cyclin } \\
\text { D }\end{array}$ & 5'-GCTCCTGTGCTGCGAAGT-3' & $\begin{array}{l}\text { 5'-TGTTCCTCGCAGA } \\
\text { CCTCCAG-3' }\end{array}$ \\
\hline $\begin{array}{l}\text { Cyclin } \\
\text { E }\end{array}$ & $\begin{array}{l}\text { 5'-GTTATAAGGGAGAC } \\
\text { GGGGAG-3' }\end{array}$ & 5'-TGCTCTGCTTCTTACCGCTC-3' \\
\hline Ptch1 & $\begin{array}{l}\text { 5'-GGGTGGCACAGTCAAGAA } \\
\text { CAG-3' }\end{array}$ & $\begin{array}{l}\text { 5'-TACCCCTTGAAGTGCTCG } \\
\text { TACA-3' }\end{array}$ \\
\hline Smo & 5'-ACGAGGACGTGGAGGGCTG-3' & $\begin{array}{l}\text { 5'-CGCACGGTATCGGTAGTT } \\
\text { CT-3' }\end{array}$ \\
\hline noggin & $\begin{array}{l}\text { 5'-CCATCATTTCCGAGTGCA } \\
\text { AGTGCT-3' }\end{array}$ & $\begin{array}{l}\text { 5'-AAGCTAGGTCTCTGTAGC } \\
\text { CCAGAA-3' }\end{array}$ \\
\hline IGFBP3 & 5'-TGCCCAGAAAATGAAAAAGG-3' & $\begin{array}{l}\text { 5'-GGATGACACAGCGT } \\
\text { GAGAGA -3' }\end{array}$ \\
\hline FGFR2 & $\begin{array}{l}\text { 5'-GATAAATACTTCCAATGC } \\
\text { AGAAGTGCT-3' }\end{array}$ & $\begin{array}{l}\text { 5'-TGCCCTATATAATTGGAG } \\
\text { ACCTTACA-3' }\end{array}$ \\
\hline D2 & $\begin{array}{l}\text { 5'-ACTTCCTGCTGGTCTACA } \\
\text { TTGATG-3' }\end{array}$ & $\begin{array}{l}\text { 5'-CTTCCTGGTTCTGGTGCT } \\
\text { TCTTC-3' }\end{array}$ \\
\hline
\end{tabular}

\section{Animal studies}

All animals were treated in accordance with protocols approved by the Institutional Animal Care and Use Committee (IACUC) at CHA University. C57BL/6 mice were obtained from Orient Bio Inc. (South Korea). Sixweek-old mice in telogen were shaved on the dorsal surface using animal clippers and hair removal agents, and then the depilated area was rinsed with sterile water. Five micrograms of Shh proteins was administered to the shaved dorsal surface of the mice by intradermal injections once a day for 14 days. In order to estimate the density and length of hair growth, the mice were anesthetized using a mixture of isoflurane (Hana Pharm, Korea) and regularly photographed with a digital camera. The hair growth was evaluated by image analysis as follows: percentage of area equals black hairy area/hair removal area.

\section{Results}

The Shh gene coding 24-197 amino acids was directly amplified from human cDNA library by PCR. The amplified DNA was cloned downstream T7 promoter in pET15b plasmid, which was subsequently transformed into E. coli strain BL21(DE3)pLys.S. The transformants were cultivated in LB medium containing ampicillin, and the expressed proteins were analyzed by SDS-PAGE. Shh protein with $25 \mathrm{KDa}$ as an expected molecular weight was expressed but not easily detectable in wholecell lysates. In order to enhance the Shh expression in $E$. coli, we constructed an expression vector in which the 20 amino acids in the $5^{\prime}$ end region of the Shh were randomly modified based on the wobble hypothesis (Crick, 1966). Surprisingly, among 60 colonies tested for the expression of Shh, four colonies designating as $\operatorname{Shh}(\# 6)$, Shh(\#10), Shh(\#16), and Shh(\#22) showed the expression of Shh protein remarkably (Fig. 1a). The DNAs of these colonies were subsequently prepared and fully sequenced (Fig. 1b).

For further purification of Shh protein, clone Shh(\#6) was selected and subjected to large-scale preparation. After cell lysis by sonication, most of Shh proteins were observed in soluble fractions. The supernatant was subjected to a $\mathrm{Ni}^{2+}$-chelating column chromatography and then was eluted with increasing imidazole concentrations (Fig. 2a). Because the eluted proteins contain $6 \mathrm{xHis}$ followed by a thrombin cleavage site in the N-terminus, they were incubated with thrombin (Fig. 2b). After cleavage with thrombin, the mixture was reapplied to the $\mathrm{Ni}$ NTA column in order to remove the $6 x H i s$ tag. The overall yield was $2.0 \mathrm{mg}$ of intact Shh over 95\% purity from $1 \mathrm{~L}$ cultures.

To determine whether the purified Shh proteins can activate the hedgehog canonical pathway, we observed their capability to activate Gli-mediated transcription in NIH3T3 fibroblasts. To make it, we generated the reporter construct p8XGBE-Luc in which eight tandem copies of Gli-binding element (GACCACCCA) are immediately proximal to the TATA box and is linked a luciferase gene (Fig. 3a). For normalization of transfection efficiency, an RSV promoterdriven $\beta$-galactosidase reporter plasmid (pRSV- $\beta$ GAL) was used. When NIH3T3 cells were transiently co-transfected with p8XGBE-Luc and pRSV-BGAL, followed by the treatment of Shh protein for $24 \mathrm{~h}$, the Shh protein activated luciferase reporter activity up to approximately 10 -fold in a 


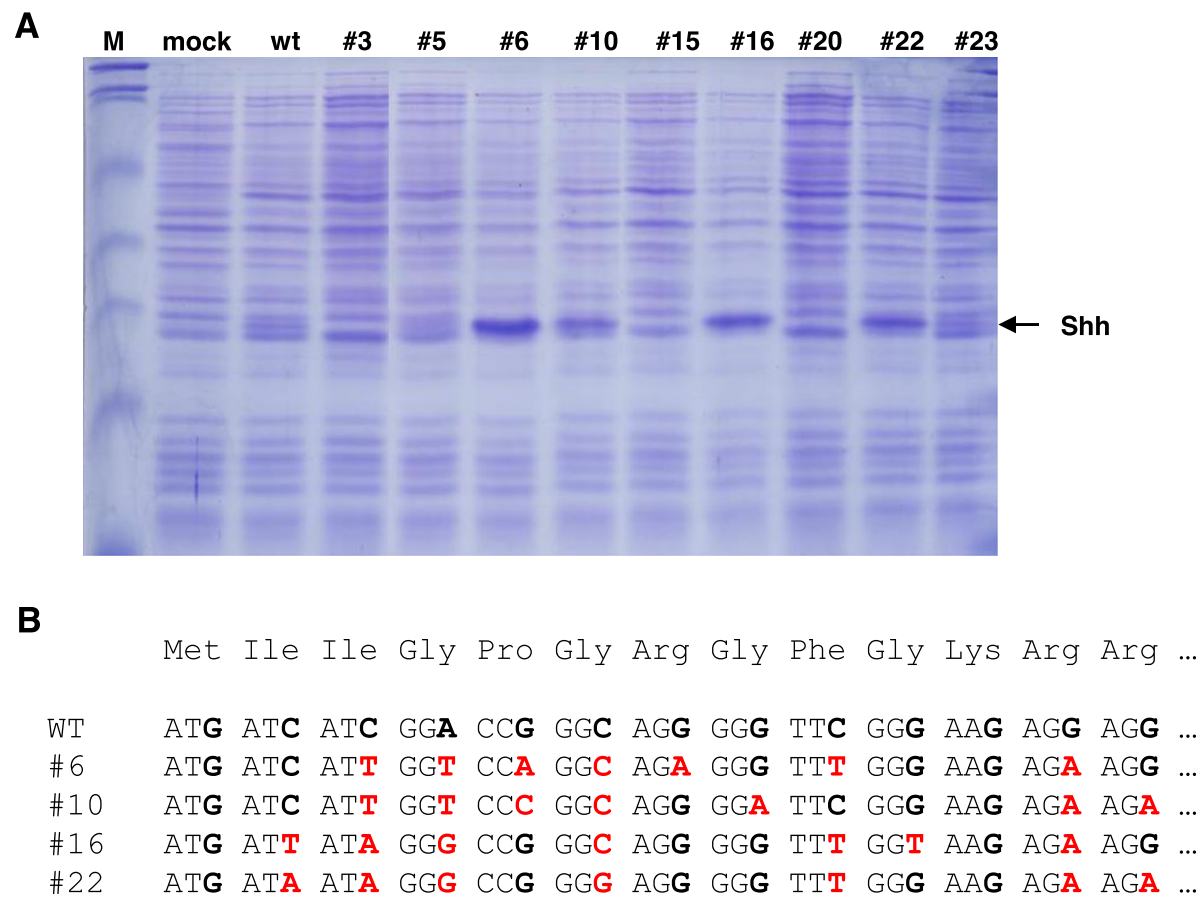

Fig. 1 Expression of Shh protein in E. coli BL21(DE3)pLysS by making silent mutations in 12 amino acids from N-terminus of Shh. a SDS-PAGE analysis of the expression of Shh in which the 20 amino acids in the $5^{\prime}$ region randomly changed. Lane $\mathrm{M}$, molecular-mass marker; lane mock,

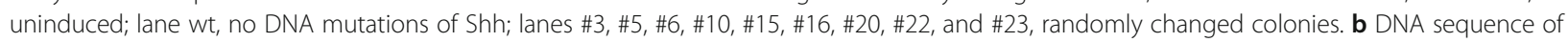
colony \#6, \#10, \#16 and \#22 were shown

dose-dependent manner (Fig. 3b). These data verify the robust activity of purified Shh protein on Gli-mediated transcription.

$\mathrm{C}_{2} \mathrm{C}_{12}$ is a mouse myoblast cell line that differentiates into the osteoblasts in the presence of BMP-4. To investigate whether Shh may have an effect on the osteoblast commitment, $\mathrm{C}_{2} \mathrm{C}_{12}$ cells were cultured in the presence of Shh, BMP-4, or both. As shown in Fig. 3c, BMP-4 alone induced AP activity of $\mathrm{C}_{2} \mathrm{C}_{12}$ cells compared with control unstimulated cells. The combination of Shh and BMP-4 further increased the AP activity, suggesting the Shh's role in the osteoblastic commitment in murine $\mathrm{C}_{2} \mathrm{C}_{12}$ cells. Together, our results indicate the evidence of functional Shh proteins by showing both the increase of the Gli-mediated transcription and the expression of the osteoblast marker AP in respond to BMP-4.

\section{A}

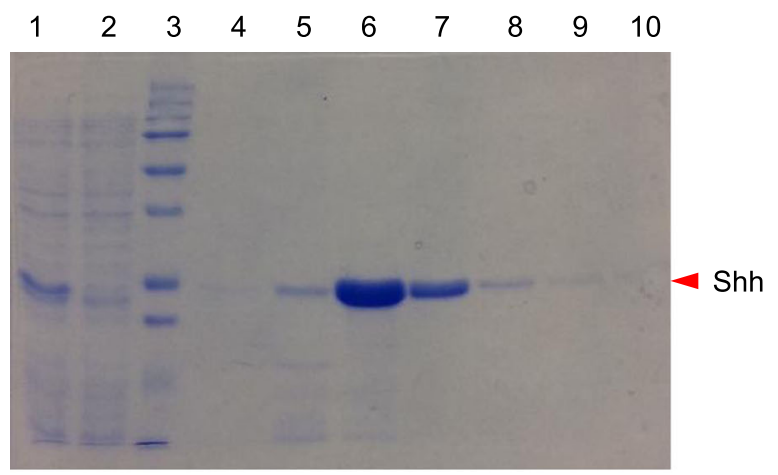

B

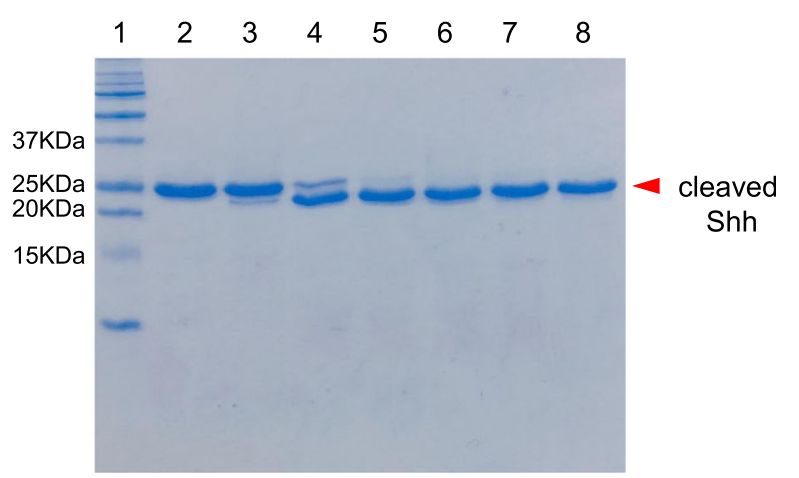

Fig. 2 Purification of the Shh protein with affinity chromatography. a SDS-PAGE analysis of the purification of Shh protein by Ni-affinity chromatography. Lane 1, lysate supernatant; lane 2, flow-through fraction; lane 3, molecular-mass marker; lanes 4-10, eluted with 20, 50, or 250 $\mathrm{mM}$ imidazole, respectively. b Purification of Shh by removing the His tag with thrombin. Lane 1, molecular-mass marker; lane 2, prior to digestion; lanes 3-8, after digestion for 2, 5, 10, 20, 30, and 40 min 


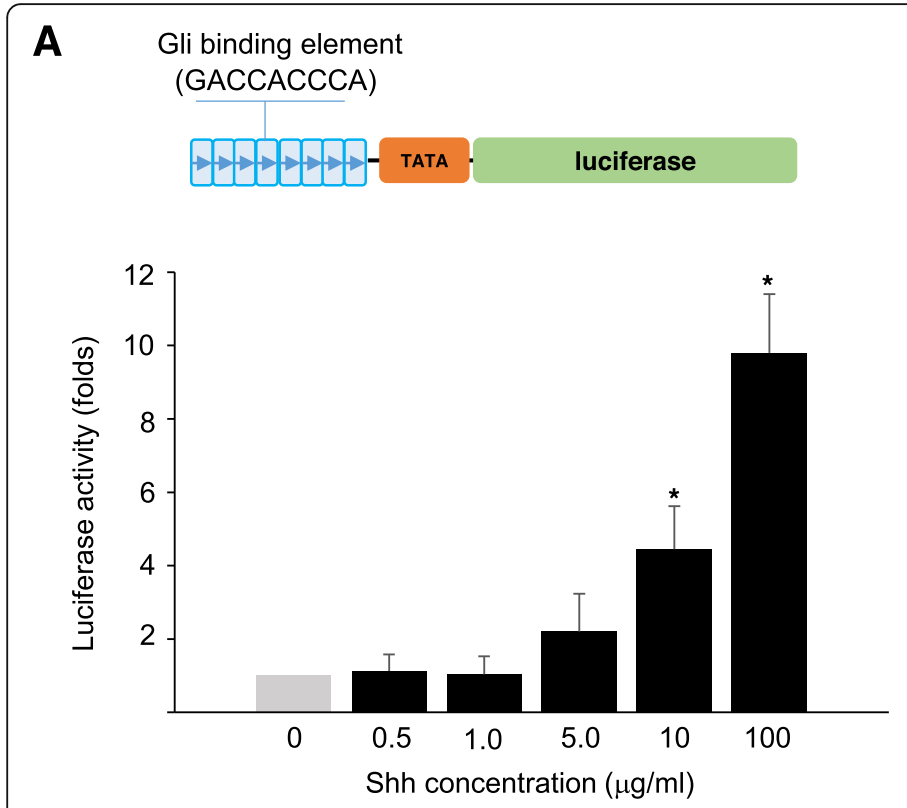

\section{B}

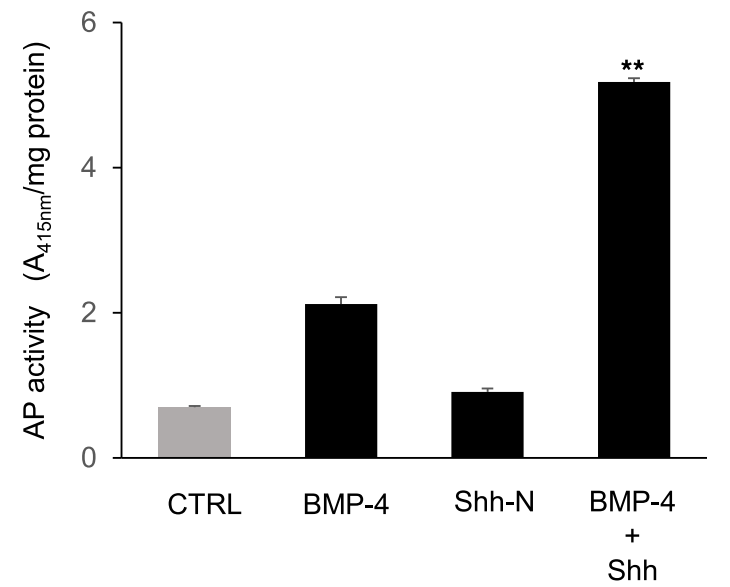

Fig. 3 Bioactivity of purified recombinant Shh proteins. a Upper panel represents the schematic diagram of plasmid p8XGBE-Luc. Lower panel shows that Shh increases Gli-mediated reporter activity. NIH3T3 cells transfected with p8XGBE-luc and pRSV- $\beta$ GAL were stimulated during $18 \mathrm{~h}$ with $0.5,1.0,5.0,10$, and $100 \mu \mathrm{g} / \mathrm{ml}$ of purified Shh. Bars represent the mean SEM of the firefly to $\beta$-galactosidase activity ratio of three independent experiments and are expressed as the fold with respect to no treatment. $\mathbf{b} \mathrm{C}_{2} \mathrm{C}_{12}$ cells were cultured in the presence of BMP-4 (50 $\mathrm{ng} / \mathrm{ml})$, Shh-N $(500 \mathrm{ng} / \mathrm{ml})$, or both for $72 \mathrm{~h}$. CTRL cells were not treated with any proteins. AP activity was measured in cell lysates and normalized to total protein concentration. ${ }^{*} p<0.05$ and ${ }^{* *} p<0.005$ vs. untreated. Error bars represent standard deviations

Shh signaling has an important role in the development and morphogenesis of the hair follicle (Oro \& Higgins, 2003). It also contributes to dermal papillae (DP) formation and hair growth by controlling the expression of a subset of DP-specific genes (Woo et al., 2012). To investigate whether the treatment of Shh proteins affects the Shh-responsive genes in hDP cells, we tested the expression for components and target genes of the hedgehog (Hh) signaling pathway, including the transmembrane receptors patched-1 (Ptch1), cyclin D (CycD), cyclin E $(\mathrm{CycE})$, and the downstream transcription factors Gli1, Gli2, and Gli3. Quantitative PCR data indicated that expression of the Hh pathway component and target genes were significantly elevated through the treatment of Shh in a dose-dependent manner (Fig. 4). Based on the critical role of $\mathrm{Wnt} / \beta$-catenin signaling pathway and versican expression in the development of hair follicle growth, we investigated whether $\beta$-catenin and versican expression could be induced by the treatment of Shh to hDP cells. As expected, exogenous Shh increased both $\beta$-catenin and versican mRNA level (Fig. 5), suggesting that Shh-N protein may be useful for new hair follicle formation or growth by increasing the versican expression and activating $\mathrm{Wnt} / \mathrm{\beta}$-catenin signaling pathway.

Next, we examined the enhancement of hair density and length by an administration of Shh proteins based on the hypothesis that hair follicle morphogenesis and hair growth are affected by Shh signaling. To test whether Shh may directly promote hair growth in vivo, dorsal skin of 6week-old C57BL/6 mice were injected with Shh proteins and compared with control mice that received PBS injections. The density and length of hair on the mouse dorsal skin were evaluated at the site of injection. After 7 days of Shh injection, the hair density and the hair length were increased by 1.2 -fold $(87.0 \pm 11.5$ vs. $72.2 \pm 12.6 \%)$ and by 1.7 -fold ( $6.6 \pm 0.5$ vs. $3.9 \pm 0.7 \mathrm{~mm} ; p<0.05)$ compared with the control group (NT), respectively (Fig. 6a, b). Although there was no significant difference in the density of hair at 14 days compared to 7 days, the hair growth showed a 1.6-fold increase $(9.0 \pm 0.8$ vs. $5.7 \pm 0.5 \mathrm{~mm} ; p<$ 0.05 ) by injection of Shh proteins at 14 days. Together, these results demonstrate the potential role of Shh in the promotion of hair growth.

\section{Discussion}

A number of signaling molecules including the Shh signaling pathway and Wnt/ $\beta$-catenin pathway has an important role in the initiation and maintenance of the anagen phase of hair cycle. In hair follicle development, $\mathrm{Wnt} / \beta$-catenin pathway is involved to the first dermal signal for hair formation and Shh signaling pathway acts later in hair follicle morphogenesis. In addition, Shh signaling contributes to hair growth and dermal papillae formation by regulating the hair follicle formation. 
Ptc1

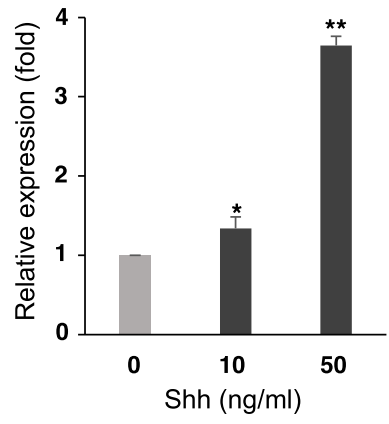

Gli3

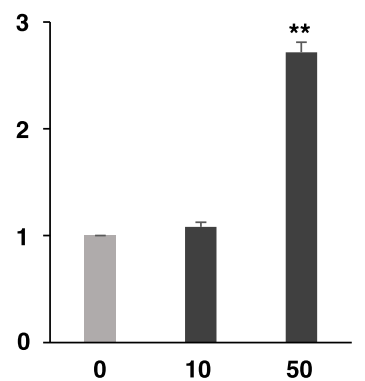

Gli1

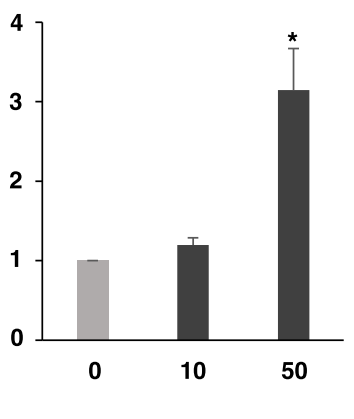

CycD

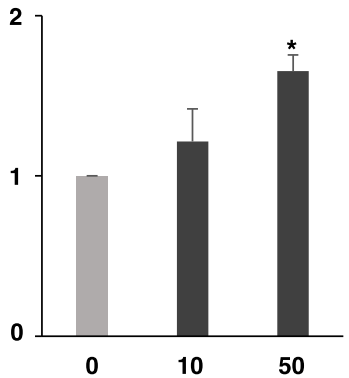

Gli2

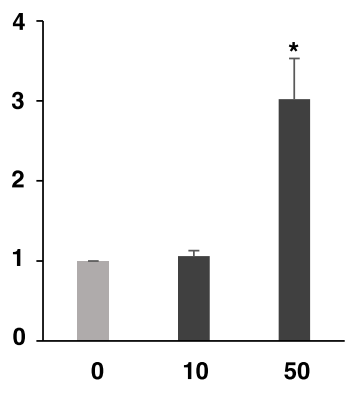

CycE

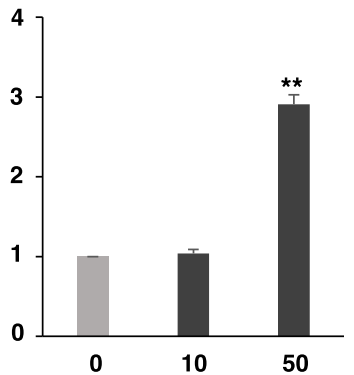

Fig. 4 Administration of Shh protein increased Shh signaling gene expression in hDP cells. Total RNA was extracted from hDP cells after Shh (10 and $50 \mathrm{ng} / \mathrm{ml}$, respectively) treatment. The increasing expression of Ptch1, Gli1, Gli2, Gli3, CycD, and CycE mRNA was observed in Shhconcentration dependent manner. Values were normalized to GAPDH mRNA levels and represent fold changes as compared to untreated cells. ${ }^{*} p<0.05$ and ${ }^{* *} p<0.005$ vs. untreated. Error bars represent standard deviations

Given the functional role in hair follicle morphogenesis and hair growth, Shh would be a potential candidate for the promotion of hair growth or prevention of hair loss. In support of this, the loss-of-function animal model demonstrated that a fetal skin from mouse Shh homozygous mutants (Shh-/-) failed to form mature hair follicles and hair shafts (Chiang et al., 1999; St-Jacques et al., 1998). In addition, gain-of-function studies in a mouse model showed that overexpression of Shh accelerated the transition from telogen to anagen in the hair cycle, leading to promote hair growth, suggesting the potential therapeutic role of Shh for promotion of hair growth or prevention of hair loss.

To prepare active recombinant Shh proteins, we initially expressed the Shh gene, which accounts for all known signaling activity (Lee et al., 1994). However, the
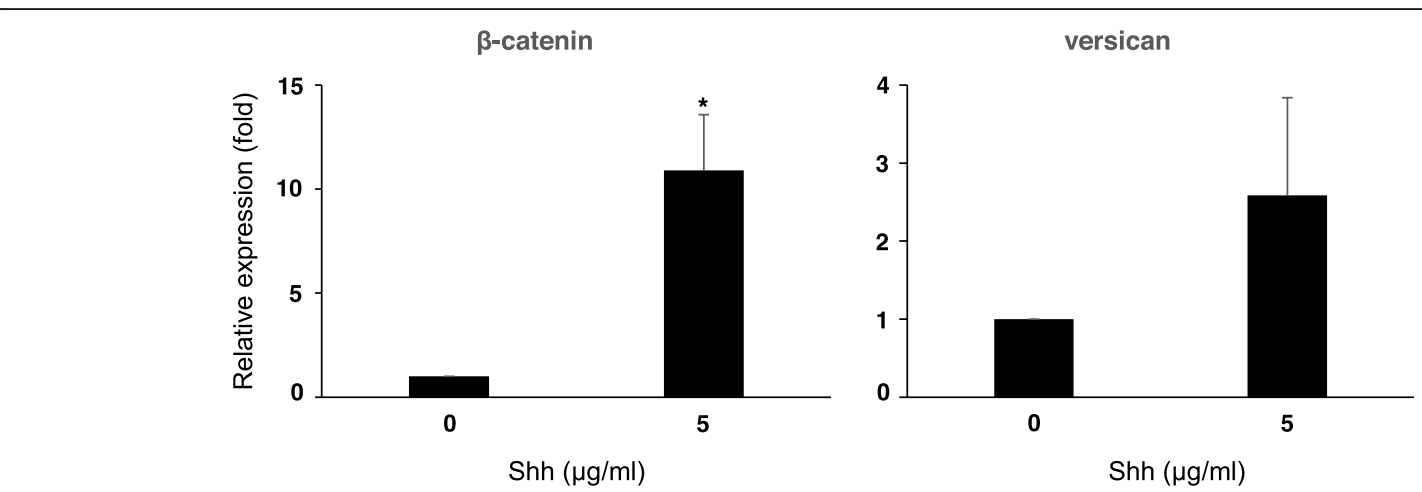

Fig. 5 Treatment of Shh protein up-regulated the gene expression related to hair-growth in hDP cells. hDP cells were treated with $5 \mu \mathrm{g} / \mathrm{ml}$ of Shh proteins. Expression of $\beta$-catenin and versican in the Shh-treated hDP cells was increased compared to that in the non-treated cells. Values were normalized to GAPDH mRNA levels and represent fold changes as compared to untreated cells. ${ }^{*} p<0.05$ vs. untreated. Error bars represent standard deviations 

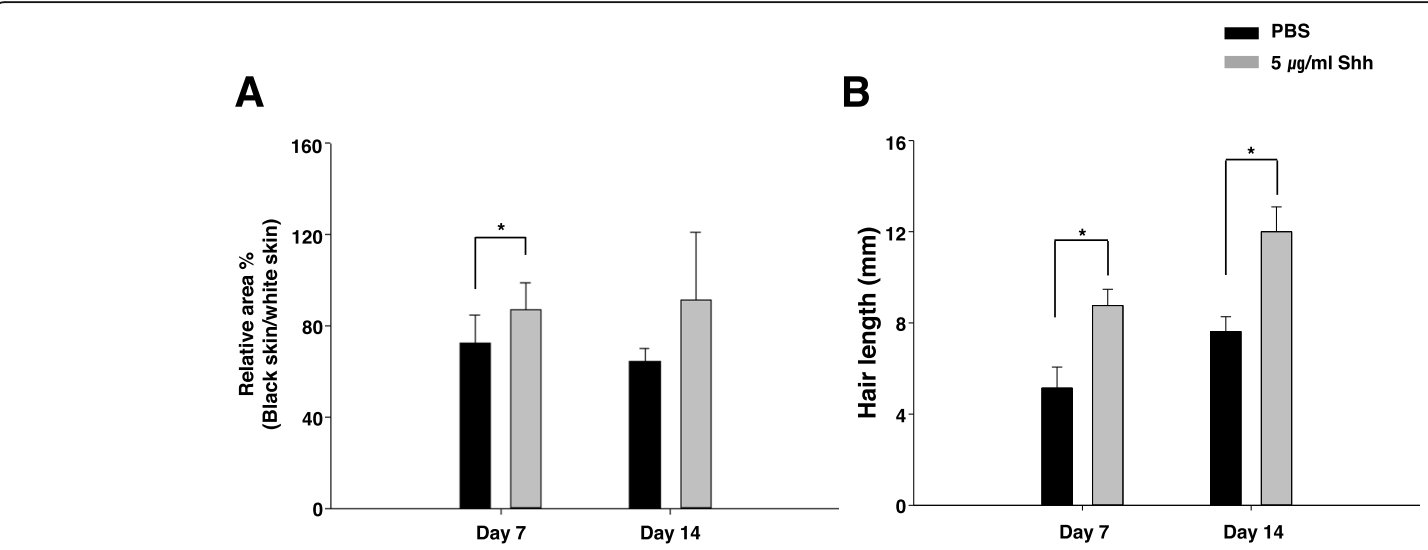

Fig. 6 Administration of Shh-N proteins increased not only the hair density but also the hair length in vivo. After depilation, the skin on the back was injected daily with the vehicle (PBS, black bar) or $5 \mu \mathrm{g} / \mathrm{ml}$ of Shh-N (gray bar). Photographed and measurement of the length of the hair in each animal were taken on days 7 and 14. Compared to the PBS-treated animal, Shh-N-treated mice showed higher hair density and longer hair

expression of the Shh protein in E. coli was too poor to be feasible (Fig. 1). Sequences downstream of ShineDalgarno (SD) have been known to affect the expression level of heterologous proteins in E. coli. For example, Klompus et al. reported that nucleotide substitutions in the $5^{\prime}$ of the cDNA encoding $\mathrm{N}$-terminal amino acids 2-11 of human interleukin 11 enhanced the protein production in E. coli (Klompus et al., 2008). It has been reported that the change of GC nucleotide content and codon usage in the $\mathrm{N}$-terminus domain of human growth hormone greatly enhanced the heterologous gene expression in E. coli (Ghavim et al., 2017). Mutagenesis of the signal peptide sequence of target protein also improved the secretion of heterologous protein in bacteria (Caspers et al., 2010). Based on these previous reports, we modified the nucleotide sequences corresponding to the initial 20 amino acids of Shh protein without changing the amino acid sequence using degenerate PCR. By mutagenesis, we successfully found several clones capable of strong expression. The results show that the variation of nucleotide sequences without amino acid change may be optimized to improve for efficient production of heterologous proteins in E. coli, and would be directly useful to improve the expression of any heterologous protein.

The Hh signaling pathway is negatively regulated by the patched receptor which represses the downstream pathway and the smoothened receptor. Shh binding to patched relieves patched repression of Smo, leading to Gli activation (Taipale et al., 2000). The mouse myoblast $\mathrm{C}_{2} \mathrm{C}_{12}$ cells can differentiate into bone cell lineage in the presence of BMP via Shh signaling pathway (Kinto et al., 1997). Based on the functional and biological role of Shh, we measured the bioactivity of Shh proteins prepared in this study using both a Gli-mediated transcriptional activation assay (Sasaki et al., 1997) and a BMP-mediated AP assay (Nakamura et al., 1997). The
Gli-luciferase assay showed that recombinant Shh protein showed its ability to efficiently activate a canonical reporter (Fig. 3a). In addition, we found that Shh protein in the presence of BMP-4 significantly increased the AP activity, indicating that Shh proteins prepared in this study are functionally active.

To date, a number of growth factors have been involved in hair follicle development and hair cycle maintenance (Danilenko et al., 1996). DP-specific signals such as FGF7 and TGF $\beta$ are required to initiate the anagen phase (Greco et al., 2009; Oshimori \& Fuchs, 2012) while Wnt3 and BMP6 are necessary for the DP hair inductive function (Rendl et al., 2008; Kishimoto et al., 2000). DP-specific $\mathrm{Wnt} / \beta$-catenin has a role in inducing new hair and maintaining hair growth in the anagen phase (Enshell-Seijffers et al., 2010a; Enshell-Seijffers et al., 2010b). Both noggin and Shh signaling play a critical role in the hair follicle morphogenesis and development via a reciprocal Noggin-Shh signaling loop (Woo et al., 2012). Our data showed that the administration of Shh proteins to hDP cells could induce the expressions of a subset of genes such as Shh signaling components (Ptch and Gli) and hair follicle growth ( $\beta$-catenin and versican) of which expressions are upregulated in anagen phase and downregulated in telogen phase (Sato et al., 1999; Paladini et al., 2005; Oro \& Higgins, 2003; Botchkarev et al., 2001), suggesting the functional role of Shh proteins in hair growth.

Next, we investigated the hair growth-promoting activity of Shh-N protein using C57BL/6 mice in the stable telogen phase. The shaved dorsal skins of C57BL/6 were directly injected with $5 \mu \mathrm{g}$ of Shh protein for 14 days. At 7 days, Shh protein significantly induced hair growth in telogenic C57BL/6 mice compared with the control group (Fig. 6a). To further investigate the hair growthpromoting effect, we randomly picked 10 hairs from the center area of each mouse and measured the hair length. 
We found that the hair length of Shh-treated group was significantly longer than that of the control group (Fig. 6b). The hair-promoting activities of Shh protein may be mediated by the enhanced expression of Gli and Ptc1, which occurs over the course of anagen and hair growth (Paladini et al., 2005). In addition, the activation of Wnt $/ \beta$-catenin pathway and upregulation of versican genes by Shh treatment may contribute the hair growth in vivo.

In conclusion, exogenous Shh proteins promote hair growth by stimulating both Shh signaling pathway and Wnt $/ \beta$-catenin pathway. These results also suggest that exogenous Shh is sufficient to initiate the Shh signaling in DP cells, induce the hair-related gene expression (Figs. 4 and 5), and therefore result in the promotion of hair growth. Taken together, these results suggest that Shh protein promotes hair growth by inducing Shh signaling genes and might therefore be a potential hairpromoting agent.

\section{Conclusions}

Shh proteins were successfully overexpressed in E.coli by making silent mutations in 12 amino acids from $\mathrm{N}$ terminus of Shh. Administration of purified Shh proteins to human DP cells induced hair-related gene expression by stimulating both the Shh signaling pathway and Wnt/ $\beta$-catenin pathway in DP cells, suggesting that recombinant Shh proteins can be a potential hair-promoting agent

\section{Acknowledgements}

Not applicable

\section{Authors' contributions}

$\mathrm{SHY}, \mathrm{YK}, \mathrm{NJ}, \mathrm{NK}, \mathrm{JCH}$, and YL performed in vitro experiments and analyzed the data. JWH, MJK, and YSC performed in vivo experiments and analyzed the data. $\mathrm{KH}$ and $\mathrm{CHK}$ designed all experiments and wrote the manuscript. All authors read and approved the final manuscript

\section{Funding}

This work was financially supported by the Ministry of SMEs and Startups (MSS), Korea, under the "Regional Specialized Industry Development Program (R0006426 to K Han)" supervised by the Korea Institute for Advancement of Technology (KIAT)

\section{Availability of data and materials}

The datasets analyzed during the current study are available from the corresponding author on reasonable request.

\section{Ethics approval and consent to participate}

Protocols for animal study were approved by the Institutional Animal Care and Use Committee (IACUC) at CHA University.

\section{Consent for publication}

Not applicable

\section{Competing interests}

The authors declare that they have no competing interests.

\section{Author details}

'Paean Biotechnology, Inc., 160 Techno-2-ro, Yuseong-gu, Daejeon 34028, South Korea. ${ }^{2}$ Department of Biotechnology, CHA University, Seongnam 13488, South Korea.
Received: 29 May 2019 Accepted: 23 October 2019

Published online: 06 December 2019

\section{References}

Botchkarev VA, Botchkareva NV, Nakamura M, Huber O, Funa K, Lauster R, Paus R, Gilchrest BA. Noggin is required for induction of the hair follicle growth phase in postnatal skin. FASEB J. 2001;15(12):2205-14.

Caspers M, Brockmeier U, Degering C, Eggert T, Freudl R. Improvement of Secdependent secretion of a heterologous model protein in Bacillus subtilis by saturation mutagenesis of the $\mathrm{N}$-domain of the AmyE signal peptide. Appl Microbiol Biotechnol. 2010;86(6):1877-85.

Chiang C, Swan RZ, Grachtchouk M, Bolinger M, Litingtung Y, Robertson EK, Cooper MK, Gaffield W, Westphal H, Beachy PA, et al. Essential role for Sonic hedgehog during hair follicle morphogenesis. Dev Biol. 1999;205(1):1-9.

Crick FH. Codon--anticodon pairing: the wobble hypothesis. J Mol Biol. 1966; 19(2):548-55.

Dallob AL, Sadick NS, Unger W, Lipert S, Geissler LA, Gregoire SL, Nguyen $\mathrm{HH}$, Moore EC, Tanaka WK. The effect of finasteride, a 5 alpha-reductase inhibitor, on scalp skin testosterone and dihydrotestosterone concentrations in patients with male pattern baldness. J Clin Endocrinol Metab. 1994;79(3):703-6.

Danilenko DM, Ring BD, Pierce GF. Growth factors and cytokines in hair follicle development and cycling: recent insights from animal models and the potentials for clinical therapy. Mol Med Today. 1996:2(11):460-7.

Enshell-Seijffers D, Lindon C, Kashiwagi M, Morgan BA. Beta-catenin activity in the dermal papilla regulates morphogenesis and regeneration of hair. Dev Cell. 2010b;18(4):633-42.

Enshell-Seijffers D, Lindon C, Wu E, Taketo MM, Morgan BA. Beta-catenin activity in the dermal papilla of the hair follicle regulates pigment-type switching. Proc Natl Acad Sci U S A. 2010a;107(50):21564-9.

Ghavim M, Abnous K, Arasteh F, Taghavi S, Nabavinia MS, Alibolandi M, Ramezani M. High level expression of recombinant human growth hormone in Escherichia coli: crucial role of translation initiation region. Res Pharm Sci. 2017;12(2):168-75.

Greco V, Chen T, Rendl M, Schober M, Pasolli HA, Stokes N, Dela Cruz-Racelis J, Fuchs E. A two-step mechanism for stem cell activation during hair regeneration. Cell Stem Cell. 2009:4(2):155-69.

Kinto N, Iwamoto M, Enomoto-Iwamoto M, Noji S, Ohuchi H, Yoshioka H, Kataoka H, Wada Y, Yuhao G, Takahashi HE, et al. Fibroblasts expressing Sonic hedgehog induce osteoblast differentiation and ectopic bone formation. FEBS Lett. 1997;404(2-3):319-23.

Kishimoto J, Burgeson RE, Morgan BA. Wnt signaling maintains the hair-inducing activity of the dermal papilla. Genes Dev. 2000;14(10):1181-5.

Klompus S, Solomon G, Gertler A: A simple novel method for the preparation of noncovalent homodimeric, biologically active human interleukin 10 in Escherichia coli-enhancing protein expression by degenerate PCR of 5' DNA in the open reading frame. Protein Expr Purif 2008, 62(2):199-205.

Lee JJ, Ekker SC, von Kessler DP, Porter JA, Sun Bl, Beachy PA. Autoproteolysis in hedgehog protein biogenesis. Science. 1994;266(5190):1528-37.

Meidan VM, Touitou E. Treatments for androgenetic alopecia and alopecia areata: current options and future prospects. Drugs. 2001;61(1):53-69.

Nakamura T, Aikawa T, Iwamoto-Enomoto M, Iwamoto M, Higuchi Y, Pacifici M, Kinto N, Yamaguchi A, Noji S, Kurisu K, et al. Induction of osteogenic differentiation by hedgehog proteins. Biochem Biophys Res Commun. 1997; 237(2):465-9.

Oro AE, Higgins K. Hair cycle regulation of Hedgehog signal reception. Dev Biol. 2003;255(2):238-48

Oshimori N, Fuchs E. Paracrine TGF-beta signaling counterbalances BMPmediated repression in hair follicle stem cell activation. Cell Stem Cell. 2012; 10(1):63-75.

Paladini RD, Saleh J, Qian C, Xu GX, Rubin LL. Modulation of hair growth with small molecule agonists of the hedgehog signaling pathway. J Invest Dermatol. 2005:125(4):638-46.

Rendl M, Polak L, Fuchs E. BMP signaling in dermal papilla cells is required for their hair follicle-inductive properties. Genes Dev. 2008;22(4):543-57.

Sasaki H, Hui C, Nakafuku M, Kondoh H. A binding site for Gli proteins is essential for HNF-3beta floor plate enhancer activity in transgenics and can respond to Shh in vitro. Development. 1997;124(7):1313-22.

Sato N, Leopold PL, Crystal RG. Induction of the hair growth phase in postnatal mice by localized transient expression of Sonic hedgehog. J Clin Invest. 1999; 104(7):855-64. 
Stenn KS, Paus R. Controls of hair follicle cycling. Physiol Rev. 2001;81(1):449-94 St-Jacques B, Dassule HR, Karavanova I, Botchkarev VA, Li J, Danielian PS, McMahon JA, Lewis PM, Paus R, McMahon AP. Sonic hedgehog signaling is essential for hair development. Curr Biol. 1998:8(19):1058-68.

Taipale J, Chen JK, Cooper MK, Wang B, Mann RK, Milenkovic L, Scott MP, Beachy PA. Effects of oncogenic mutations in Smoothened and Patched can be reversed by cyclopamine. Nature. 2000;406(6799):1005-9.

Wang LC, Liu ZY, Gambardella L, Delacour A, Shapiro R, Yang J, Sizing I, Rayhorn P, Garber EA, Benjamin CD, et al. Regular articles: conditional disruption of hedgehog signaling pathway defines its critical role in hair development and regeneration. J Invest Dermatol. 2000;114(5):901-8.

Woo WM, Zhen HH, Oro AE. Shh maintains dermal papilla identity and hair morphogenesis via a Noggin-Shh regulatory loop. Genes Dev. 2012 26(11):1235-46

\section{Publisher's Note}

Springer Nature remains neutral with regard to jurisdictional claims in published maps and institutional affiliations.

Ready to submit your research? Choose BMC and benefit from:

- fast, convenient online submission

- thorough peer review by experienced researchers in your field

- rapid publication on acceptance

- support for research data, including large and complex data types

- gold Open Access which fosters wider collaboration and increased citations

- maximum visibility for your research: over $100 \mathrm{M}$ website views per year

At BMC, research is always in progress.

Learn more biomedcentral.com/submissions 